\title{
Impact of snow state variation for design flood simulations in glacierized catchments
}

\author{
J. Schöber ${ }^{1,2}$, S. Achleitner ${ }^{3}$, R. Kirnbauer ${ }^{4}$, F. Schöberl ${ }^{2}$, and H. Schönlaub ${ }^{5}$ \\ ${ }^{1}$ alpS - Centre for Climate Change Adaptation Technologies, Innsbruck, Austria \\ ${ }^{2}$ Institute of Geography, University of Innsbruck, Austria \\ ${ }^{3}$ Unit of Hydraulic Engineering, University of Innsbruck, Austria \\ ${ }^{4}$ Institute for Hydraulic and Water Resources Engineering, Vienna University of Technology, Austria \\ ${ }^{5}$ TIWAG - Tiroler Wasserkraft AG, Innsbruck, Austria
}

Correspondence to: J. Schöber (schoeber@alps-gmbh.com)

\begin{abstract}
A continuously running hydrological energy balance model was used to analyse the influence of different snow covers on the formation of large floods within glacierized catchments. Model outputs from three different catchments in the Austrian Alps with glacierizations ranging from 30 to $39 \%$ were statistically interpreted to cover a wide range of possible combinations of areal snow cover distribution and mean snow water equivalent $\left(\mathrm{SWE}_{\mathrm{m}}\right)$ and to define initialisation values for extreme runoff scenarios. These model states consider snow conditions between less than $10 \%$ snow coverage up to almost complete snow coverage, with different snow depths represented by minimum, mean or maximum levels of $\mathrm{SWE}_{\mathrm{m}}$. For the utilization of extreme runoffs, these snow cover states were combined with design storm input data. An analysis of the resulting flood hydrographs showed that the maximum runoff values occur with minimal snow cover conditions. With increasing snow coverage and $\mathrm{SWE}_{\mathrm{m}}$, flow magnitudes tend to decrease while the relevant precipitation time increases significantly. The influence of topographical catchment features, snow cover and $\mathrm{SWE}_{\mathrm{m}}$ on the simulated scenario discharge is discussed. The contribution of the different runoff components to the modelled peak flows confirms the assumption that floods in glacierized catchments are a combination of directly discharging rain and ice melt.
\end{abstract}

\section{Introduction}

Floods in alpine areas are mainly induced by heavy precipitation. Topographic catchment features, as well as the current state of water storage (e.g. snow coverage or soil moisture), have an additional impact on the discharge magnitude. For example, snow melt can lead to saturated soils and thus increased base flow rates (Reszler et al., 2008). In highly elevated catchments of the Alps, glacierized and snow covered areas dominate and soils are developed on only a moderate areal proportion. Consequently, ice- and snow-related melt processes are important flood-producing factors in combination with heat advection and rainfall (Parajka et al., 2010).

The focus in this work was put on the glacierized catchments in the Austrian province of Tyrol. The utilized hydrological model, SES (Asztalos et al., 2007), is a continuouslyrunning water balance model and part of the flood forecasting system HoPI (Schöber et al., 2010). The main benefit of a water balance model is that it provides system states, such as soil saturation or snow cover, which have a significant impact on the runoff generation (Marchi et al., 2010). For the case of design floods, Franchini et al. (1996) showed a significant effect of antecedent moisture conditions on the magnitude of the simulated extreme runoffs. In basins where the accumulation and melt of snow has an influence on the runoff regime, maximum floods which develop during the snowmelt season are seen as critical for design purposes (Stallings, 1987). In the case study area, where snow- and ice- melt have an influence on the runoff regime, antecedent snow cover conditions are analysed for their impact on the formation of floods. Therefore, three catchments with different areas, topography and precipitation regimes were chosen for the investigation. Hourly simulated snow cover storage states of the years of 1995 to 2009, such as mean catchments snow water equivalent $\left[\mathrm{SWE}_{\mathrm{m}} ; \mathrm{mm}\right]$ and areal distribution of the snow coverage [\%] were analysed. During this period climatic extremes occurred, such as one of the most intense heat waves ever to be 

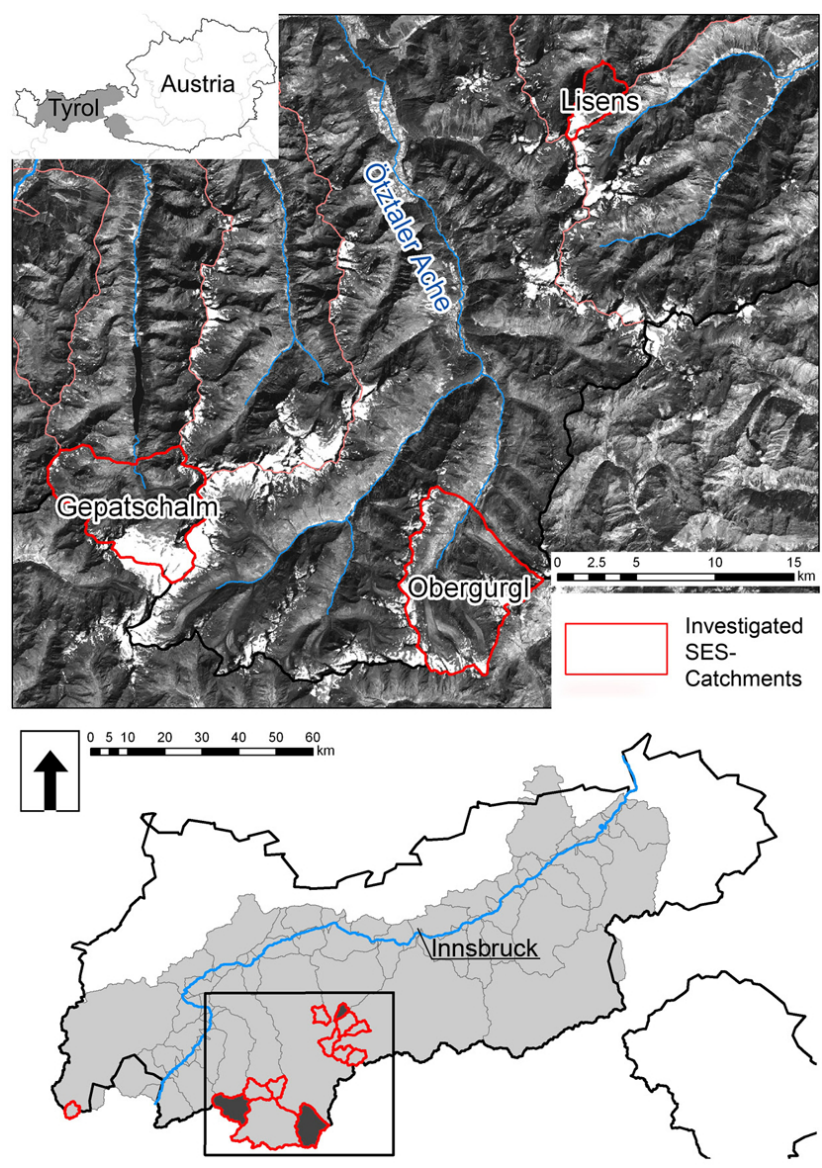

Fig. 1. Glacierized catchments within the model area of the flood forecasting system of the river Inn (gray) with emphasis on the three catchments analysed in this study.

observed in Western Europe in the summer of 2003 (Beniston and Diaz, 2004). In the year 1999, one of the severest avalanche catastrophes in Austrian history happened in Tyrol. With respect to snow hydrology, the period is of interest due to the large snow depths occurring. Thus, simulated extreme runoffs can be based on model states within a large range of realistic snow cover states.

In addition to the initial states, emphasis is put on the different runoff producing processes involved in the catchment. For instance, the quantities of precipitation stored as snow is determined by the level of the snowline (Rinderer et al., 2008). A high snowline increases the direct runoff that can occur in combination with melt forcing processes and can consequently lead to flood situations. Such effects were observed in alpine areas of Southern Germany where heavy rainfall was introduced to an existing snow cover and even accelerated the snow melt processes (Sui and Koehler, 2001). In contrast, the event description of a flood event in the Ötztal in 1987 - a partly glacierized catchment in Tyrol - concludes that the energy input of rain into a snow pack played only a minor role for the runoff formation (Steinacker,

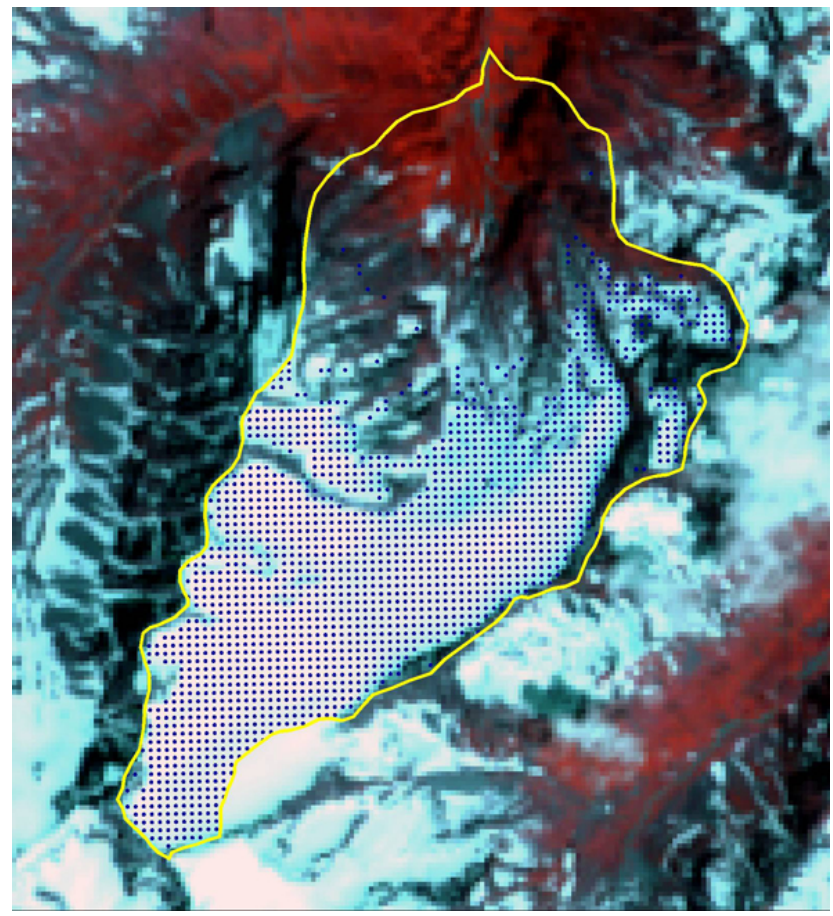

Fig. 2. Landsat image of Lisens catchment on 30 June 2001 showing an overall agreement between observed and simulated (blue dots) snow cover of $89 \%$ (statistical scenario features of this snow state: $\left.\mathrm{SCQ}=30 \%, \mathrm{SWE}=\mathrm{SWE}_{\mathrm{m}, \max }\right)$.

1988). But if the snow cover becomes saturated due to rainfall, the washout of free water in the snow cover is accelerated. Further, the retention capacity of snow-free glaciers is small and can lead to a subsequent runoff without any delay similar to what occurs on sealed surfaces.

\section{Data and models}

\subsection{HoPI and SES}

The water balance model used, SES (Snow- and Ice melt model; Asztalos, 2004), is part of the flood forecasting system HoPI (Hochwasserprognose für den Tiroler Inn) for the Austrian province of Tyrol. It utilizes a spatially-distributed energy balance approach; the accumulation and melting processes for snow, firn, and ice are considered. The internal processes of the snow pack are parameterized, including the concepts of water retention and cold content (Braun, 1985). The applied retention capacity of the snowpack is $10 \%$ according to Blöschl and Kirnbauer (1991). The outflow of a glacierized catchment is routed via five parallel Nashcascades (Nash, 1960) concerning different surface facies (snow, firn, ice, rock and sub-surface flow) and the associated retention times. The HoPI system has a data processing module which provided the meteorological input data which was used for calibration and validation. Input data requirements 


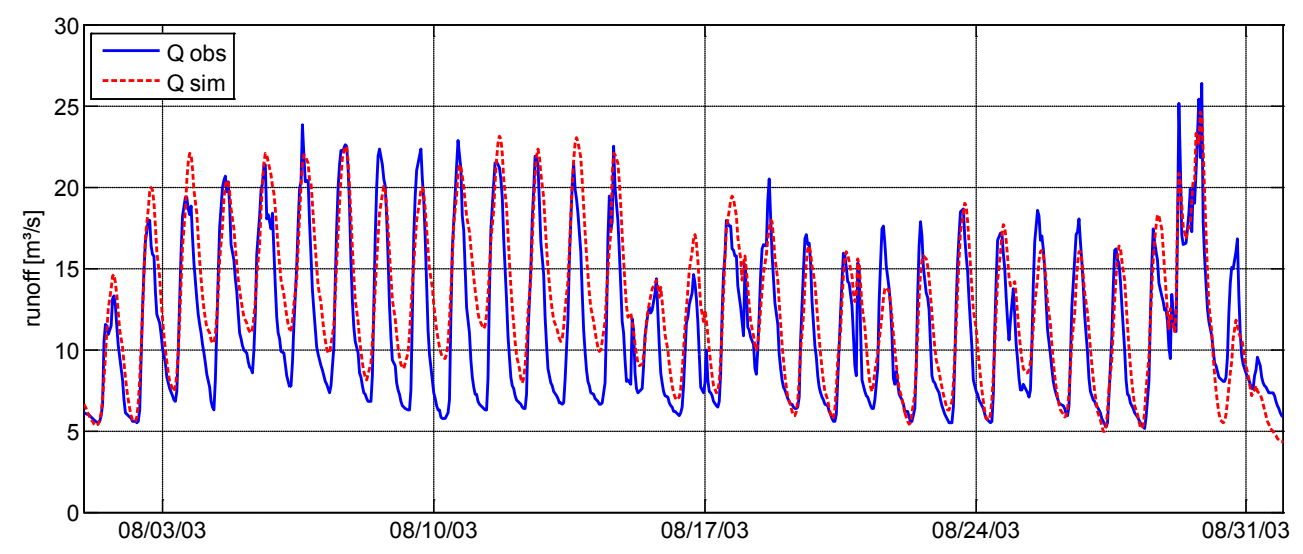

Fig. 3. Observed and simulated flow in hourly resolution for Gepatschalm catchment in August 2003 including the state of 29 August 2003 which represented the minimum snow cover in each of the analysed catchments.

for simulations using SES are precipitation, temperature with according lapse rates, global radiation, relative humidity and wind speed. The spatial extend of HoPI can be found in Fig. 1. Details on the overall systems or specific model components can be found in Kirnbauer et al. (2009), Schöber et al. (2010) and Achleitner et al. (2012).

The SES model-catchments were calibrated using observed flow data and remotely-sensed spatially-distributed snow cover data within the period 1994-2009. Amongst other remote sensing sources, Landsat images (e.g. Dozier and Marks, 1987) were used for the calculation of an overall agreement between the observed and simulated snow covers (Fig. 2). A simulation run of 15 hydrological years without any state corrections achieved a mean overall agreement for all catchments snow cover of $79 \%$ (Schöber et al., 2010).

Hourly runoff measurements from gauged glacierized catchments were used for calibration and validation of the models runoff routing module. The validated flow parameter settings were transferred to the remaining ungauged SES-catchments. A unique set of parameters was found for both the energy balance module and the runoff module. For the present work, one ungauged catchment was chosen besides two calibrated, gauged basins. Figure 3 shows the wellmatching plots of observed $\left(Q_{\text {obs }}\right)$ and simulated $\left(Q_{\text {sim }}\right)$ runoff hydrographs during August 2003 in hourly resolution. The presented period is characterized by a strong contribution of glacier melt to the total catchment flow.

\subsection{Case study area}

Within the HoPI system, the SES model is used for simulations of the runoff of 13 glacierized catchments with areas ranging from $9 \mathrm{~km}^{2}$ to $165 \mathrm{~km}^{2}$. The selection of relevant catchments for this study was made considering area size and catchment features like glacierization and elevation (seen in Table 1). The Obergurgl basin has an area of $72 \mathrm{~km}^{2}$ and is therefore the second largest SES catch-
Table 1. Topographic features of the study areas.

\begin{tabular}{llll}
\hline & Gepatschalm & Lisens/Lisnerbach & Obergurgl \\
\hline Area [km $^{2}$ ] & 53 & 9 & 72 \\
Glacierization [\%] & 39 & 30 & 32 \\
Elevation range [m] & $1920-3518$ & $1712-3298$ & $1900-3549$ \\
Mean elevation [m] & 2841 & 2684 & 2810 \\
Mean slope $\left[^{\circ}\right.$ ] & 21.5 & 27.2 & 24.4 \\
Glacier tongue [m] & 2250 & 2680 & 2700 \\
\hline Gauged & $\mathrm{y}$ & $\mathrm{n}$ & $\mathrm{y}$ \\
\hline
\end{tabular}

ment within HoPI. The Gepatschalm basin $\left(53 \mathrm{~km}^{2}\right)$ represents a medium-sized catchment, and the Lisenerbach basin $\left(9 \mathrm{~km}^{2}\right)$ represents the smallest catchment. The two larger catchments are in the Ötztaler Alps and represent the most southern parts of the province, located directly at the alpine main ridge. The Lisenerbach catchment lies furthest to the north of all SES catchments and is part of the Stubaier Alps. Due to unequal atmospheric circulations on the north and the south side of the Alps, different precipitation regimes can be expected. Each of the two southerly catchments is characterized by a large main glacier and some smaller mountain glaciers. The Gepatschferner (Gepatschalm catchment) and the Gurglerferner (Obergurgl catchment) have sizes of roughly $16 \mathrm{~km}^{2}$ and $9 \mathrm{~km}^{2}$, respectively. The Gurglerferner is a typical alpine glacier with a distinct valley glacier tongue while the Gepatschferner has its accumulation area on a large glacierized plateau with a comparatively small and steep glacier tongue. The model catchment of Lisens can be described by a glacierized plateau of roughly $2.8 \mathrm{~km}^{2}$ and a steep non-glacierized slope leading to the valley floor (see Fig. 2).

\subsection{Concept of design flood scenarios}

It was recently shown that the water storage capacity of soils is an important aspect for the peak-runoff production and also 

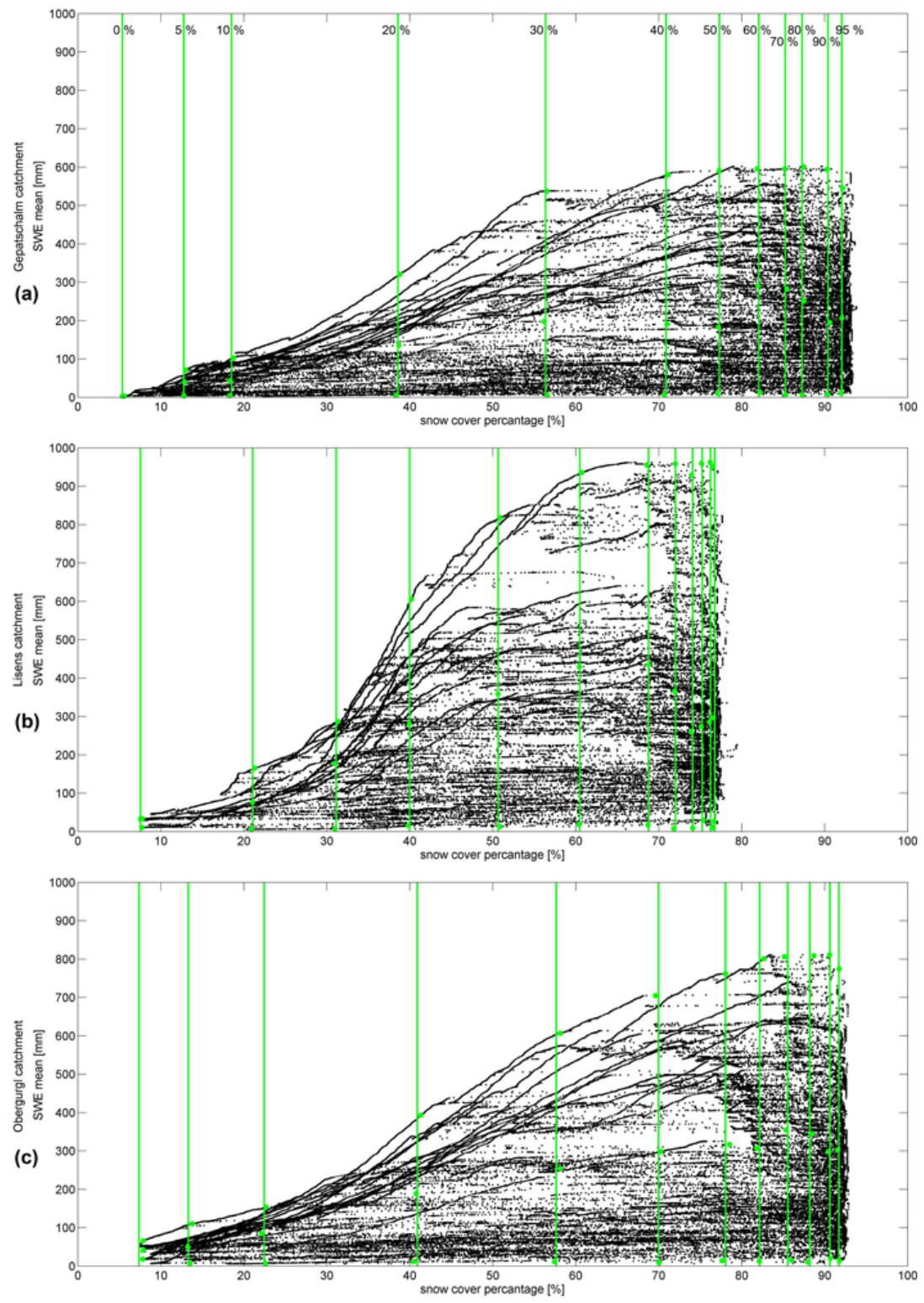

Fig. 4. Plots of simulated mean snow water equivalent $\left[\mathrm{SWE}_{\mathrm{m}} ; \mathrm{mm}\right]$ vs. snow coverage [\%] in the period of 1995-2009 for catchments (a) Gepatschalm, (b) Lisenerbach and (c) Obergurgl; Vertical green lines: snow cover quantiles (SCQ); Green dots minimum, mean or maximum $\mathrm{SWE}_{\mathrm{m}}$.

has influence on the magnitude of design floods (Franchini et al., 1996). In alpine basins snow cover can have an additional impact on the runoff; therefore, different model states were combined with large precipitation sums to evaluate the consequence of the snow cover on extreme runoffs. Since glacierized alpine areas are typical locations of reservoirs for hydropower production, where very infrequent flood peaks are utilized for the design of hydraulic structures (e.g. spillways), we decided to apply design storms with a recurrence interval of 5000 years. The model assumptions made for these extreme runoff scenarios are described in the following sections.

\subsubsection{Initial states for runoff scenarios}

The time series of the areal mean SWE [mm] and the areal distribution of snow coverage [\%] were considered as initial model states for the subsequent analysis. Scatter plots of these two variables (period 1995-2009) are displayed for the three model catchments in Fig. 4. The simulation of the first hydrological year (1994/95) was considered as model warm-up period, thus these results were excluded from the analysis. In these plots, the horizontal axis shows the mean areal coverage of snow and the vertical axis shows the range of $\mathrm{SWE}_{\mathrm{m}}$. Snow coverage ranges from about $7 \%$ to $93 \%$ 
Table 2. Design storm durations $(D)$ and associated rain sums of the Gepatschalm catchment (recurrence interval of $T=5000$ years).

\begin{tabular}{ccccccccccccc}
\hline$D[\mathrm{~h}]$ & 2 & 3 & 6 & 9 & 12 & 18 & 24 & 48 & 72 & 96 & 120 & 144 \\
\hline$[\mathrm{mm}]$ & 64.4 & 70 & 74.3 & 92 & 118.4 & 138.3 & 165.3 & 182.4 & 237.6 & 275.8 & 301.1 & 321.3 \\
\hline
\end{tabular}
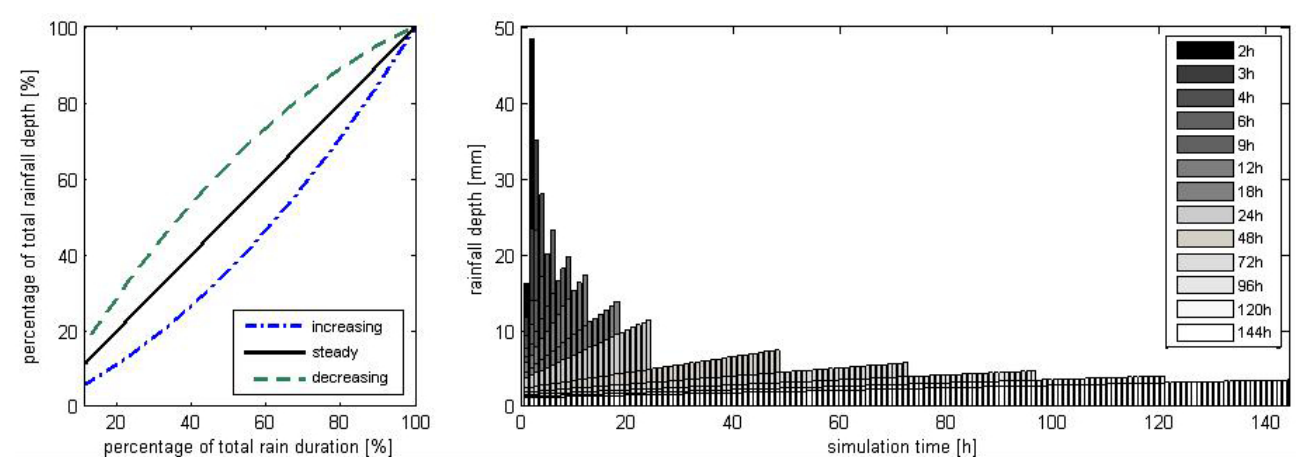

Fig. 5. Design storms with a recurrence interval of $T=5000$ years for the Gepatschalm catchment. Left side: Different temporal rainfall distributions for a 9 hour design storm. Right side: hourly rainfall depths with increasing temporal distribution in the course of the different design storm durations $(D)$.

for the Gepatschalm and the Obergurgl catchment but the maximum areal snow coverage of Lisens catchment is $78 \%$. This can be attributed to the numerous steep slopes in this catchment in combination with the model assumption that no snow accumulates on slopes steeper than $45^{\circ}$. According to the literature, e.g. Blöschl et al. (1991), this threshold varies between 35 and $70^{\circ}$. The maxima of $\mathrm{SWE}_{\mathrm{m}}$ differ significantly between the catchments, where the largest difference is found between Gepatschalm ( $\mathrm{SWE}_{\mathrm{m}, \max } \sim 600 \mathrm{~mm}$ ) and Lisens $\left(\mathrm{SWE}_{\mathrm{m}, \max } \sim 950 \mathrm{~mm}\right)$. According to Fliri (1975), a north-south gradient of annual precipitation sums with decreasing values towards the south can be found in the Tyrolean Alps.

To consider representative model initial states from the complete combinatorial variations of the two state variables, the following procedure was used. Per definition, the selection of representative parameter combinations was based on 12 quantiles of the snow coverage between $0 \%$ and $95 \%$ (see Fig. 4a for each step). The parameter sets used were selected to be in the close proximity $( \pm 0.5 \%)$ of the respective quantile values. In the vertical dimension, the minimum, maximum and mean values of $\mathrm{SWE}_{\mathrm{m}}$ in the respective classes were considered. In total, 36 parameter combinations are obtained and used as the initial states to simulate extreme (design)storm scenarios. For the case of Gepatschalm and Lisens, only one or two values of $\mathrm{SWE}_{\mathrm{m}}$ were found for the least snow covered states. Thus, the number of parameter sets reduced to 34 and 35 , respectively.

\subsubsection{Design storm input data}

For detecting the influence of the different types of snow coverage on the runoff magnitude, artificial rainfalls with a re- currence interval of $T=5000$ years were used. In Austria, design storm magnitudes (precipitation sums) are available for a $6 \mathrm{~km}$ grid covering storm durations between $5 \mathrm{~min}$ utes and 6 days. These design storms are obtained by means of the statistical analysis of extreme values of precipitation measurements combined with a deterministic model for convective precipitation events applying maximized parameter values and boundary conditions (Weilguni, 2009). The rain intensities of Gepatschalm catchment (Table 2) with a recurrence interval of $T=5000$ years were applied for all three catchments in order to analyse the differences between the catchments runoff behaviours. Rainfall durations $(D)$ of 2, 3, $6,9,12,18,24,48,72,96,120$ and 144 hours with increasing, decreasing and steady temporal distributions were used for modelling design floods. In case of the steady temporal distribution, the rainfall intensity represents simply the mean intensity over the duration based on the precipitation sum. The increasing rainfall distribution is based on a linear increase, where the first and the last time steps are the mean intensity being decreased and increased by $50 \%$, respectively. The decreasing design rainfall is distributed in reverse temporal order. The percentage of the total rainfall depth as a function of the rain duration for the three different distributions is shown in Fig. 5 (left side, example for $D=9 \mathrm{~h}$ ). The right side of Fig. 5 shows the hourly rainfall intensities for all rainfall durations having an increasing temporal distribution.

This analysis was combined with assumed values of the temperature indicating precipitation in liquid form over the entire catchment. The meteorological scenario input was accomplished with a relative humidity set at $100 \%$ and observed values of wind speed and global radiation within past storm events. The scenario input data has its start point at 

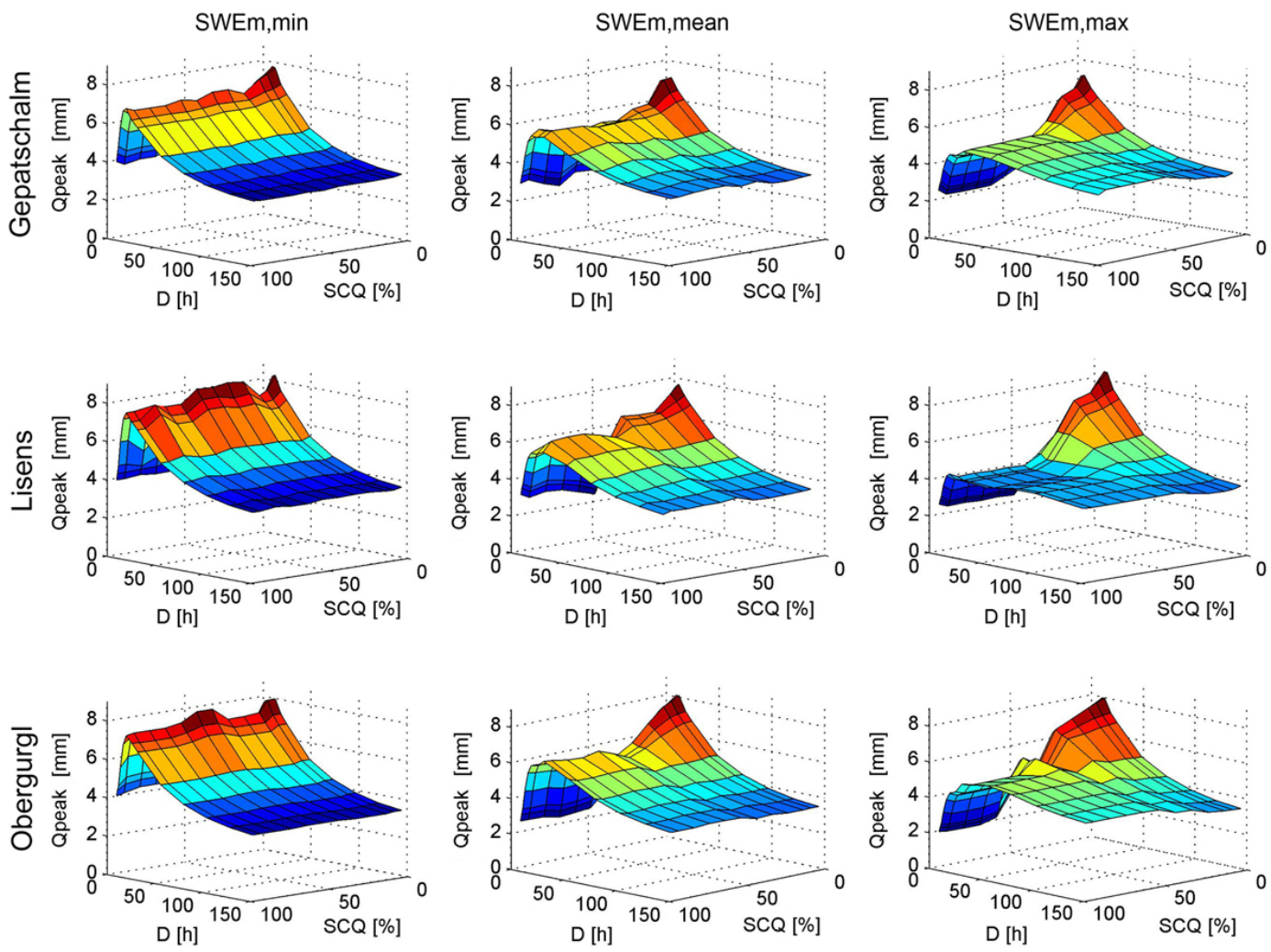

Fig. 6. Peak runoff distributions (Qpeak $[\mathrm{mm}])$ as function of storm duration $(D[\mathrm{~h}])$ and the snow cover quantile (SCQ [\%]), separated for different catchments and $\mathrm{SWE}_{\mathrm{m}}$ levels.

noon, starting with the maximum temperature of $10^{\circ} \mathrm{C}$ at the mean elevation of the catchment. In the following hours the temperature decreases linearly until the early morning hours of the following day $\left(4^{\circ} \mathrm{C}\right)$ where it starts to rise again. For the distribution of the temperature in the catchment wet adiabatic lapse rates are used. The global radiation has also a daily course with values ranging from 0 to $250 \mathrm{~W} \mathrm{~m}^{-2}$.

\section{Results and discussions}

In total, 39 rainfall combinations (13 durations with three different temporal distributions) were applied at each catchment and combined with up to 36 initial states. The peak runoff from each scenario hydrograph was used for the subsequent analysis. In order to compare the results of the differentsized catchment areas, the modelled hydrographs $\left[\mathrm{m}^{3} \mathrm{~s}^{-1}\right]$ were converted into runoff depths [mm]. In Fig. 6, nine separate plots are presented for the combinations of three catchments with min, mean and maximum $\mathrm{SWE}_{\mathrm{m}}$. In each subplot, the peak runoffs (Qpeak [mm]) are plotted against the snow cover quantile (SCQ [\%]) and the design storm duration $(D[\mathrm{~h}])$. Further, only design storm types leading to a maximum peak runoff were included. For all cases, the design storm with increasing rainfall intensity was found (as expected) to be the critical temporal distribution leading to the largest runoffs.

In all cases the critical (largest) runoff occurs for SCQ being $0 \%$. Especially for states with a small SCQ, the variability of minimum, mean or maximum of $\mathrm{SWE}_{\mathrm{m}}$ reduces significantly (compare Fig. 4), thus the $\mathrm{SWE}_{\mathrm{m}}$ has less impact than SCQ on the overall maximum runoff. Furthermore, the critical runoff in each catchment is not necessarily found at minimum or maximum values of $S W E_{m}$. The occurrence depends rather on the event history. Generally, the case study areas have the least snow cover in late summer and especially the maximum runoffs were simulated based on the initial status from 29 August 2003. This was at the end of a three month heat wave over Europe (Beniston and Diaz, 2004) which led to critical conditions in all three glacierized catchments. Regardless of the occurring level of $\mathrm{SWE}_{\mathrm{m}}$, the largest potential for the critical design flood was found at this date.

Focusing on the critical rainfall durations in the range of 9 to 24 hours, a characteristic ridge of peak values in the range of these lower storm durations can be found. For the cases with $\mathrm{SWE}_{\mathrm{m} \text {,min }}$ this ridge is very distinct and is given for the whole range of SCQ. At higher $\mathrm{SWE}_{\mathrm{m}}$ levels, the ridge exists no longer for the larger values of SCQ and is rather a peak formation when low SCQ and short storm durations are combined. 

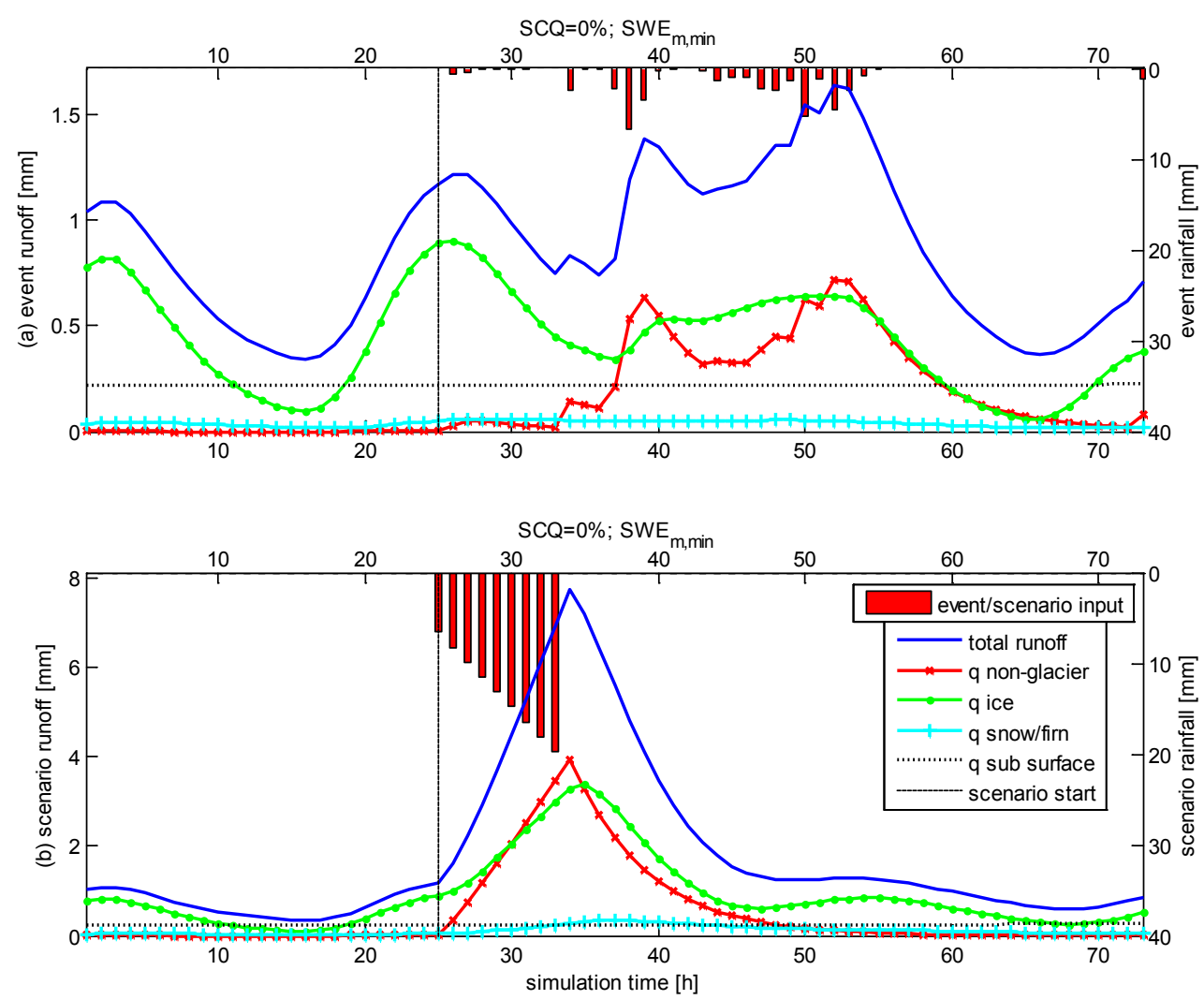

Fig. 7. Gepatschalm catchment: Simulation results with initial state conditions from 29 August $2003 ; \mathrm{SCQ}=0 \%$ and $\mathrm{SWE}=\mathrm{SWE} \mathrm{m}_{\mathrm{m}}$ min . Simulation with (a) measured rainfall and (b) design storm $(T=5000$ years, $D=9 \mathrm{~h})$ with increasing rainfall intensity.

Considering all the plots in Fig. 6 at a glance, the figure visualizes the buffering effect of snow covers in the catchment. In particular, combinations of large SCQ values (50-100\%) and large $\mathrm{SWE}_{\mathrm{m}}$ lead to smaller maximum runoffs where the peak flows are less variable with regard to different storm durations. Even larger durations lead to maximum flows but do not exceed other discharges drastically. In the catchments Gepatschalm, Lisens and Obergurgl, the largest critical design storm duration are found to be 24,96 and 48 hours respectively. The maximum values of $\mathrm{SWE}_{\mathrm{m}}$ in the catchments are around 600, 950 and $800 \mathrm{~mm}$, respectively (compare Fig. 4). Therefore, when focusing on the maximum level of $\mathrm{SWE}_{\mathrm{m}}$, the Lisens catchment has the highest retention potential of the three compared watersheds.

In order to analyse the runoff components the hydrographs of three different scenarios were investigated. First, the conditions leading to the decisive flood peak, calculated with initial values representing the end of the heat period in summer of 2003, are considered. This period was completed with a rainfall event ( 30 hours rain sum of $40 \mathrm{~mm}$ ) on $29 \mathrm{Au}-$ gust 2003 (see Fig. 3) leading to a medium annual flood event. The observed rainfall and the simulated runoff of this event is shown in Fig. 7a including the different runoff routing hydrographs from Nash cascades associated with the different model components (ice, snow, firn, ...). The antecedent runoff of this event is dominated by ice melt in combination with a stable base flow (outflow of the sub surface cascade). During the event, the additional rain induced runoff originates from the snow free non-glacierized part of the catchment. In the case of the model scenario leading to the largest peak flow ( $T=5000$ years, $D=9 \mathrm{~h}$ with increasing distribution) for this initial state (Fig. 7b), the total runoff is a combination of direct discharge of rainfall and discharges from the ice-covered parts. This second factor is a combination of ice melt water and the events rainfall discharged via the ice cascade. In both cases - the real event and the scenario simulation - snow and firn melt plays only a minor role within this flood event since the catchment was almost snow free.

In contrast, two other scenario results with two different initial snow states characterized by more distinct snow covers are displayed in Fig.8. The flood peaks of these two scenarios have approximately the same magnitude, however, the scenario hydrograph of $\mathrm{SCQ}=60 \%$ and $\mathrm{SWE}_{\mathrm{m} \text {,max }}$ (Fig. 8a) is mainly induced by the direct discharge of rain from the snow-free parts of the non-glacierized catchment area. The outflow from the snow and firn cascades increases during the event, attributable to a saturated snow pack with no retention 

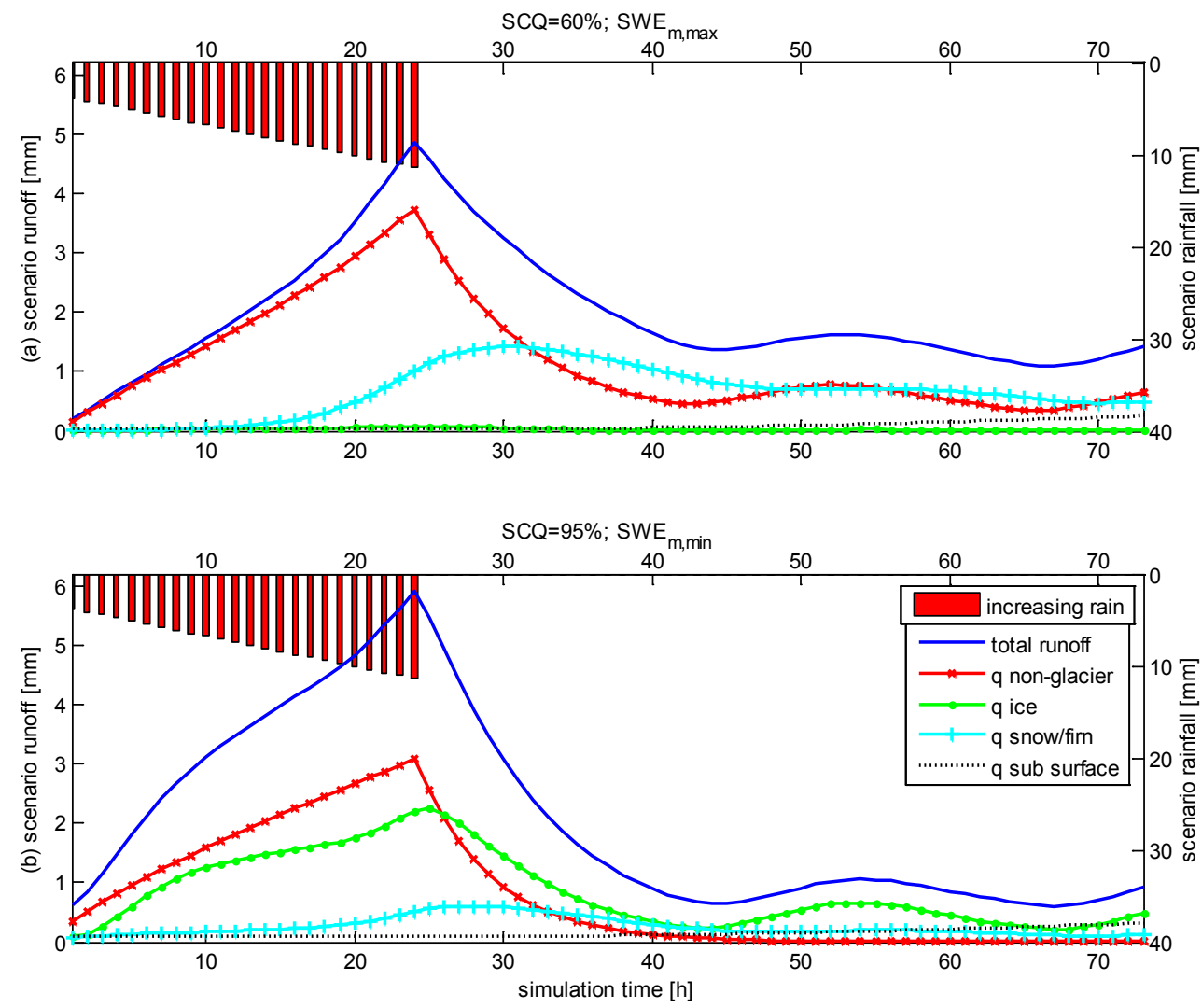

Fig. 8. Simulation results for Gepatschalm with a design storm $(T=5000$ years, $D=24 \mathrm{~h})$ with increasing rainfall intensity and varying initial state conditions (a) 5 June 2006; $\mathrm{SCQ}=60 \%$ and $\mathrm{SWE}=\mathrm{SWE}$, max (b) 3 October 1999; $\mathrm{SCQ}=95 \%$ and $\mathrm{SWE}=\mathrm{SWE}$, min .

capacity left. After the flood peak was reached, melt effects caused by positive temperatures starts. Runoff from the icecascade plays only a minor role, since most parts of the glacierized areas are covered with a snow pack still having retention capacity left. Finally, the scenario hydrograph of $\mathrm{SCQ}=95 \%$ and $\mathrm{SWE}_{\mathrm{m} \text {, min }}$ (Fig. 8b) is also mainly induced by discharging rain as well as outflow from the ice cascade. Prior to the flood peak there is only a slight contribution from the snow and firn cascades, which starts to rise only during the last hours before the maximum runoff. At the start of this scenario, the catchment's state is characterized by a shallow snow pack ( $\mathrm{SWE}_{\mathrm{m}}$ of $10 \mathrm{~mm}$ ) with a low retention capacity. After the first 24 hours of the scenario the input temperature rises and the saturated snow cover starts to melt.

The model behaviour under different input and state conditions is found to be consistent with descriptions of event dynamics in the literature (see e.g. Steinacker, 1988; Franchini et al., 1996). In all of the presented scenarios, melt due to solar radiation plays a minor role because of low values for the global radiation in the input data. Melt through rain causes only a small contribution on the total runoff. An example presented by Steinacker (1988) based on energy balance calculations showed that $20 \mathrm{~mm}$ of rain with a temperature of $4^{\circ} \mathrm{C}$ can ablate $1 \mathrm{~mm}$ of SWE. This temperature corresponds to the lower level of scenario input temperatures and the rain sum is in accordance with a 2 hours rain sum of the 12 hours scenario rain input with a steady distribution. For the given example in Fig. 8a with SCQ of $60 \%$, this would lead to a maximum melt rate of $0.3 \mathrm{~mm} / \mathrm{h}$ due to rain on snow. This melt runoff from the cell then has to be routed (delayed and damped) via its Nash cascade. Although when comparing the melt rate directly with the scenarios simulated peak flows it represents only a small fraction.

The recession limb of the scenario hydrographs is in many cases characterized by an increasing proportion of snow/firn runoff (see Fig. 8). Due to the delayed characteristic the flows may be attributed not to rainfall but to melt processes. Therefore, the relevant processes are positive temperatures in combination with wind that increases the sensitive and the turbulent heat transfers (Marks et al., 2001). Resulting from this effect, additional snow and ice melt can occur.

\section{Conclusions}

The presented work deals with the simulation of design flood flows in glacierized catchments, using extreme design storms with a recurrence period of 5000 years. As a result of these hydrological scenarios, a strong correlation between peak 
flow and the snow state was found. The largest flow peaks were simulated with initial values representing a marginal snow cover and short rainfall periods.

Additionally, this study illustrates the importance of the chosen snow states when dealing with design floods in glacierized catchments. The usage of a continuously running water balance model allows the detection of critical initialisation parameter combinations as well as the statistical evaluation of these model states. The results of this study confirm that the late summer months, with almost no snow cover in the glacierized catchments, bear the highest potential for the development of large floods. In this period, according to Parajka et al. (2010), the annual precipitation maxima typically occur. At the beginning of summer - especially in June - the remaining retention capacity of the snow pack and the non-developed glacier melt flow lead only to a medium flood potential (compare Fig. 8a). The critical design flood of all the three catchments was simulated with initial states of August 2003 due to a strong contribution of ice melt and low retention capacities of bare ice surfaces. It can be seen that this combination is a worst case combination, where maximized input (here in form of a 5000 year design storm) and the most unfavourable initial states are combined. It is worth discussing if worst case combinations are necessary for the purpose of evaluating the design discharge. The combination of the design storm with a remaining snow cover leads to lower discharges - but with an increased (more realistic?) probability of occurrence. In case the decision goes towards a probabilistic approach when combining design storms and initial model states, the changing environment may have an impact. Recent studies, which were focused on future runoffs in a changing climate found an increased flooding potential in glacierized catchments (e.g. Huss et al., 2008). However, when heat periods (like in 2003) would occur more often the general potential for floods in glacierized areas could increase.

Acknowledgements. This work has been undertaken within the frame of the alpS Project "H05 HoPI II - Enhancing Preparedness through Improved Flood Forecasting" and the Austrian Academy of Science Project "HyPCC" embedded in the International Strategy for Disaster Reduction (ISDR) program . The authors would like to thank the federal state of Tyrol, the Austrian Research Promotion Agency (FFG), the Austrian Academy of Science (ÖAW) and the TIWAG - Tiroler Wasserkraft AG who support the project. Thanks to two reviewers for their helpful comments to the manuscript.

Edited by: R. Ludwig, K. Schulz, and M. Disse

Reviewed by: two anonymous referees

\section{References}

Achleitner, S., Schöber, J., Rinderer, M., Leonhardt, G., Schöberl, F., Kirnbauer, R., and Schönlaub, H.: Analyzing the operational performance of the hydrological models in an alpine flood forecasting system, J. Hydrol., 412-413(0), 90-100, 2012.

Asztalos, J.: Ein Schnee- und Eisschmelzmodell für vergletscherte Einzugsgebiete. Master's Thesis, Vienna University of Technology, Austria, 2004.

Asztalos, J., Kirnbauer, R., Escher-Vetter, H., and Braun, L.: A distributed energy balance snow and glacier melt model as a component of a flood forecasting system for the Inn river, Proceedings of the Alpine*Snow*Workshop, Munich, 5-6 October 2006, Germany, Berchtesgaden, Berchtesgaden National Park research report, No. 53, 9-17, 2007.

Beniston, M. and Diaz, H. F.: The 2003 heat wave as an example of summers in a greenhouse climate? Observations and climate model simulations for Basel, Switzerland, Global Planet. Change, 44, 73-81, 2004.

Blöschl, G. and Kirnbauer, R.: Point snowmelt models with different degrees of complexity - internal processes, J. Hydrol., 129, 127-147, 1991.

Blöschl, G., Gutknecht, D., and Kirnbauer, R.: Distributed Snowmelt Simulations in an Alpine Catchment. 1. Model Evaluation on the Basis of Snow Cover Patterns, Water Resour. Res., 27, 12, 3171-3179, 1991.

Braun, L. N.: Simulation of snowmelt-runoff in lowland and lower alpine regions of Switzerland, Zürcher Geographische Schriften, 21, 166 pp., 1985.

Dozier, J. and Marks, D.: Snow mapping and classification from landsat thematic mapper data, Ann. Glaciol., 9, 97-103, 1987.

Fliri, F.: Das Klima der Alpen im Raume von Tirol, in: Monographien zur Landeskunde Tirols - Folge I, edited by: Leidlmair, A. and Hutter, F., Innsbruck, 1975.

Franchini, M., Helmlinger, K., Foufoula-Georgiou, E., and Todini, E.: Stochastic storm transposition coupled with rainfall-runoff modeling for estimation of exceedance probabilities of design floods, J. Hydrol., 175, 511-532, 1996.

Huss, M., Farinotti, D., Bauder, A., and Funk, M.: Modelling runoff from highly glacierized alpine drainage basins in a changing climate, Hydrol. Process., 22, 3888-3992, 2008.

Kirnbauer, R., Achleitner, S., Schöber, J., Asztalos, J., and Schönlaub, H.: Hochwasservorhersage Inn: Modellierung der Gletscherabflüsse, Mitteilungsblatt des Hydrographischen Dienstes in Österreich, Nr. 86, 109-130, http://www.lebensministerium.at/wasser/wasser-oesterreich/ wasserkreislauf/hydrographie_oesterreich/mitteilungen/ Mitteilungsblatt86.html (last access: 22 June 2012), 2009.

Marchi, L., Borga, M., Preciso, E., and Gaume, E.: Characterisation of selected extreme flash floods in Europe and implications for flood risk management, J. Hydrol., 394, 118-133, 2010.

Marks, D., Link, T., Winstral, A., and Garen, D.: Simulating snowmelt processes during rain-on-snow over a semi-arid mountain basin, Ann. Glaciol., 32, 195-202, 2001.

Nash, J.: A unit hydrograph study with particular reference to British catchments, Proc. Inst. Civ. Eng., 17, 249-282, 1960.

Parajka, J., Kohnová, S., Bálint, G., Barbuc, M., Borga, M., Claps P., Cheval, S., Dumitrescu, A., Gaume, E., Hlavcová, K., Merz, R., Pfaundler, M., Stancalie, G., Szolgay, J., and Blöschl, G.: Seasonal characteristics of flood regimes across the Alpine- 
Carpathian range, J. Hydrol., 394, 78-89, 2010.

Reszler, C., Komma, J., Blöschl, G., and Gutknecht, D.: Dominante Prozesse und Ereignistypen zur Plausibilisierung flächendetaillierter Niederschlag-Abflussmodelle, Hydrol. Wasserbewirts., 50, H.5, 220-232, 2008.

Rinderer, M., Achleitner, S., Asztalos, J., and Kirnbauer, R.: Sensitivity analysis of lapse rate and corresponding elevation of snowline - limited data availability and its impact on snow and glacier melt, in: Proceedings of the 4th International Symposium on Flood Defence, edited by: Institute for Catastrophic Loss Reduction (ICLR), 5-8 May 2008, Toronto, Canada, 2008.

Schöber, J., Achleitner, S., Kirnbauer, R., Schöberl, F., and Schönlaub, H.: Hydrological modelling of glacierized catchments focussing on the validation of simulated snow patterns applications within the flood forecasting system of the Tyrolean river Inn, Adv. Geosci., 27, 99-109, doi:10.5194/adgeo-27-992010, 2010.
Stallings, E. A.: Determination of design floods using storm data, J. Hydrol., 96, 319-328, 1987.

Steinacker, R.: Die alpinen Hochwasserereignisse des Sommers 1987, Österreichische Wasserwirtschaft, Jahrgang 40, Heft 5/6, 1988.

Sui, J. and Koehler, G.: Rain-on-snow induced flood events in Southern Germany, J. Hydrol., 252, 205-220, 2001.

Weilguni, V.: Bemessungsniederschläge in Österreich, Wiener Mitteilungen, 216, 71-84, 2009. 